\title{
Threats Identification and Human-African Elephant Interactions in Kafta-Shiraro National Park, Tigray, Ethiopia
}

\author{
Kalayu Mesfin Arefayne, Kibrom Gebremariam, Gebrekidan Kidanemariam and Frehaymanot Haylay \\ Biology Department, Aksum University, P.O. Box: 1010
}

\begin{abstract}
The main objective of the study was to identify the major threats of African elephant in Kafta-Shiraro National Park, Tigray, Ethiopia. The data was collected using questionnaires, interview, discussion with key informants and direct field observation. Currently Kafta-Shiraro National Park was affected by many threats such as Agricultural encroachments $\left(1^{\text {st }}\right)$, Traditional mining extraction $\left(2^{\text {nd }}\right)$, Deforestation $\left(3^{\text {rd }}\right)$, Charcoal production $\left(4^{\text {th }}\right)$, Irrigation activity $\left(5^{\text {th }}\right)$, Fire $\left(6^{\text {th }}\right)$ and Illegal hunting and poaching $\left(7^{\text {th }}\right)$ ranking based on the field observation and questionnaire from respondents. Among the main sources of conflict between human-African elephant in the national park were crop damage (57\%), competition for resources $(19 \%)$, necessity of guarding field $(12 \%)$, destruction of property $(8 \%)$ and people killed by elephant $(4 \%)$. Habitat disturbance, livestock interference, feed shortage and illegal hunting were the main threats of African elephant in the park. Poor community awareness, high population, frees access for resources, weak law enforcement and poor patrolling were the major problems for effective management of elephants in the park. After analyzed the data African elephant conservation training were given for 40 community representatives for 6 consecutive days. Finally the office of the national park should work in collaboration with the local community in order to solve the current threats of the park to sustainable resources for the next generation.
\end{abstract}

Keywords: African Elephant, Conservation, Human- elephant conflict, Threats

DOI: $10.7176 /$ JNSR/12-9-05

Publication date:May $31^{\text {st }} 2021$

\section{INTRODUCTION}

Ethiopia has diverse wildlife populations which are comparable, species wise to other countries of east Africa. Inventory of the wildlife potential of the country indicates that there are 260 species and sub-species of mammals, 845 species of birds, 78 species of snakes, 54 species of amphibians and 101 species of fish (EWCO, 1988).

Kafta-Sheraro National Park (Kafta-Sheraro NP), was recognized as Park in 2007 by the regional government of Tigray, is situated in the northwest of Ethiopia between $13^{\circ} 50^{\prime}$ and $14^{\circ} 23^{\prime} \mathrm{N}$ and $36^{\circ} 31^{\prime}$ and $37^{\circ} 29^{\prime}$ E. It is bordered by Eritrea in the North and it is presumed to have an estimated total area of 2176.34 $\mathrm{km}^{2}$, with mosaic woodlands of Combretum-Terminalia, Acacia-Commiphora, Dry-evergreen montane, scrubland and riparian vegetation (Mekbeb et al., 2001). The Park was registered among the 73 Important Bird Areas in Ethiopia. Besides supporting the remnant elephant population in the expanse of the Tekeze Valley and home to many ungulates, predators and a variety of birds.

The elephant is widely recognized as one of the continent's most important flagship species and a potential flagship species for the national park itself. The species is of considerable economic and ecological importance to the region. For the poor elephant number in the park is associated with different problems. People and animals are increasingly coming into conflict over living space and food as human populations continue expanding and natural habitats shrink. The impacts are often huge, with crop and livestock losses, and even cases of people losing their lives. The animals, many of which are already threatened or endangered, are sometimes killed in retaliation or to 'prevent' future conflicts.

\section{Research questions}

At the end of the study the following research questions was solved

1. What are the main communities based conservation strategies of African elephant's (Loxodanta africana) habitats?

2. What are the roles of communities based conservation strategies of African elephant's (Loxodanta africana) habitats for ecotourism development?

3. What are the relationship between the national biodiversity conservation strategies with the local communities based conservation strategies towards African elephant's (Loxodanta africana) habitats in Kafta-sheraro national park

\section{METHODOLOGY}

The study was conducted in Kafta-Sheraro National Park, northwest Ethiopia. Kafta-Sheraro The main reason to select the area was because the park is currently one among the nine separate and isolated Elephant populations established in Ethiopia. 


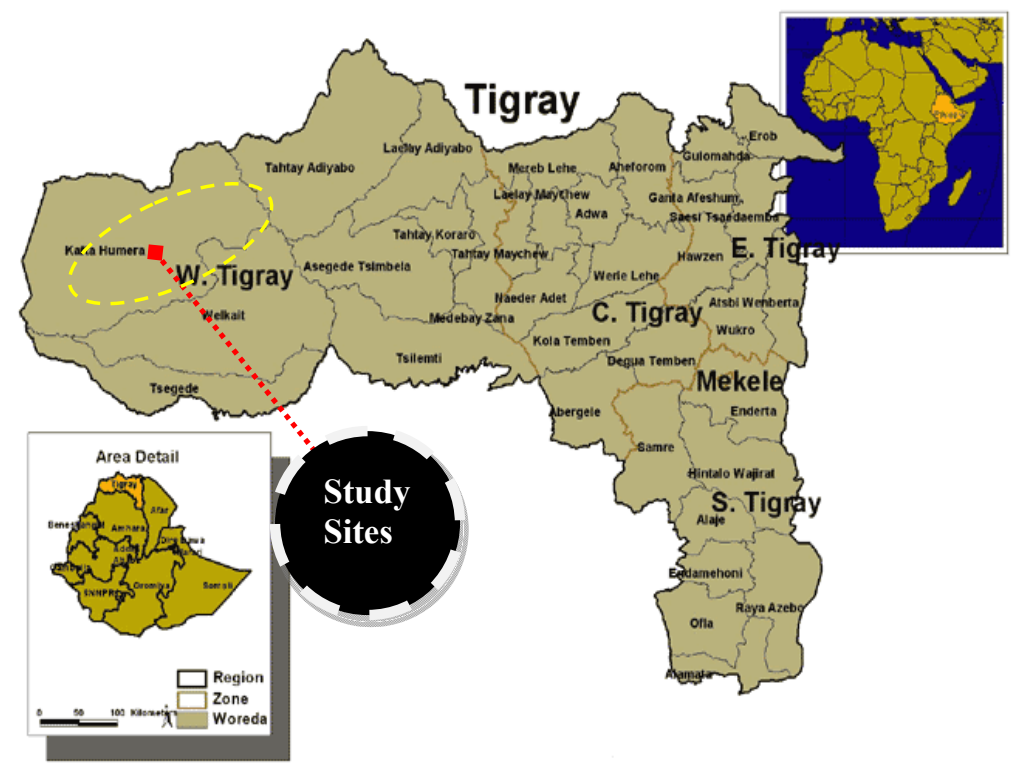

Fig 1: Study site

\section{Data collection and analysis}

Data was collected from both primary and secondary sources. Primary data sources was obtained from the household survey through structured questionnaire consisting of both open and close-ended questions, direct insitu observation, focus group discussion and key informants interviews based on set of questions in relation to the study objectives. A checklist was prepared for gathering information from key informants and for the focus group discussion. Secondary information was obtained through an extensive literature review of various documents and an internet search. For this survey a stratified random sampling technique was used. The stratification was, based on villages distance to the park, sex of the respondents, level of education, land type and years of resided with a total sample size of 150 respondents from Villages of Hilet koka in Adebay (Kunama), Adebay (Habesha), Freselam, Wudet, Mayweyni (Gytsi), Kunam Adigoshu, Habesha Adigoshu, Maykeyh, Tekeze and Adi-aser. In addition to this ten focus group discussion was included from the Villages. The respondents were selected using stratified random sampling techniques. A semi-structured questionnaire was distributed to 150 respondents. Finally data was analyzed using SPSS ver. 16.0 and the Microsoft excel. The data was mainly expressed as descriptive statistics such as frequency, percentages, and graphs.

\section{RESULTS AND DISCUSSION}

Causes of human-African elephant conflict in Kafta-Shiraro National Park

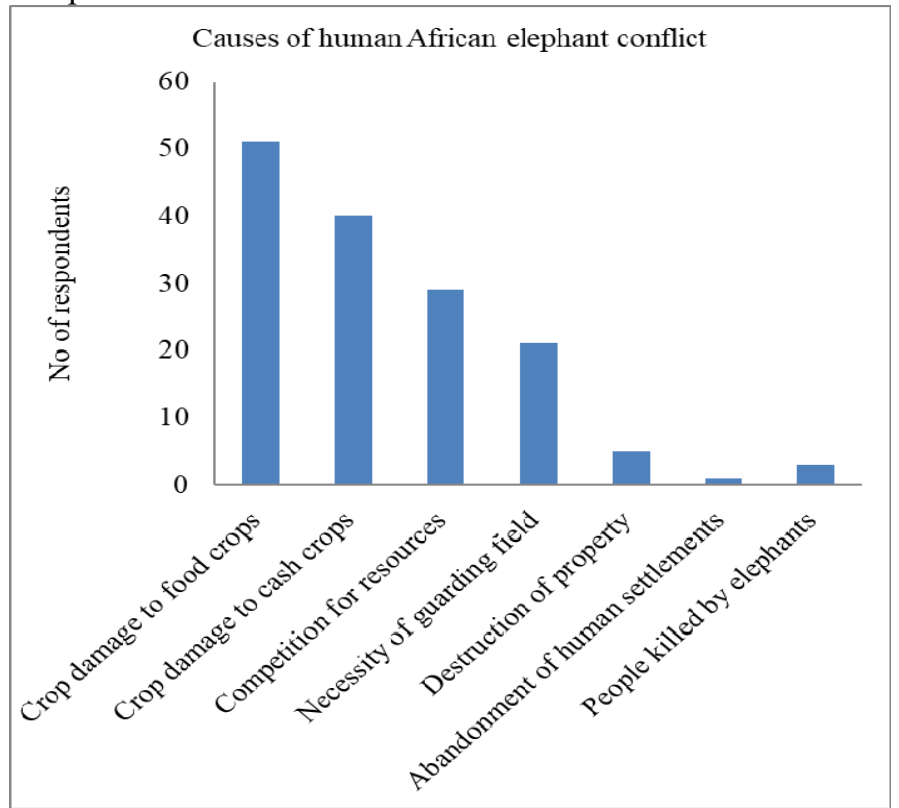

Fig 2: Causes of human-African elephant conflict in Kafta-Shiraro National Park 
As the above figure indicated that crop damage to food crops was the main cause for human African elephant conflict followed by crop damage to cashes crops, competition for resources, necessity of guarding field, destruction of property and people killed by elephants were among the causes of human-African elephant conflict in Kafta-Shiraro National Park. This might be some food crops such as sorghum was highly preferred by African elephant source of food. Abandonment of human settlement was the least cause for the Human-African elephant conflict in the park this might be most of the villages were far away from the park. The current finding is in line with previous study by Dawit Mamo, 2012 conducted in Kafta Shiraro National Park regarding the threats of the national park such as poor patrolling and poor community awareness. However regarding the human elephant conflict the present finding was disagreeing with previous finding by Ananda et al., 2001). Because as his finding indicated that that the most important predictor of human-elephant conflicts on this particular landscape is neither the number of settlements, nor the extent of road development.

Major problems for effective management of elephants in the park

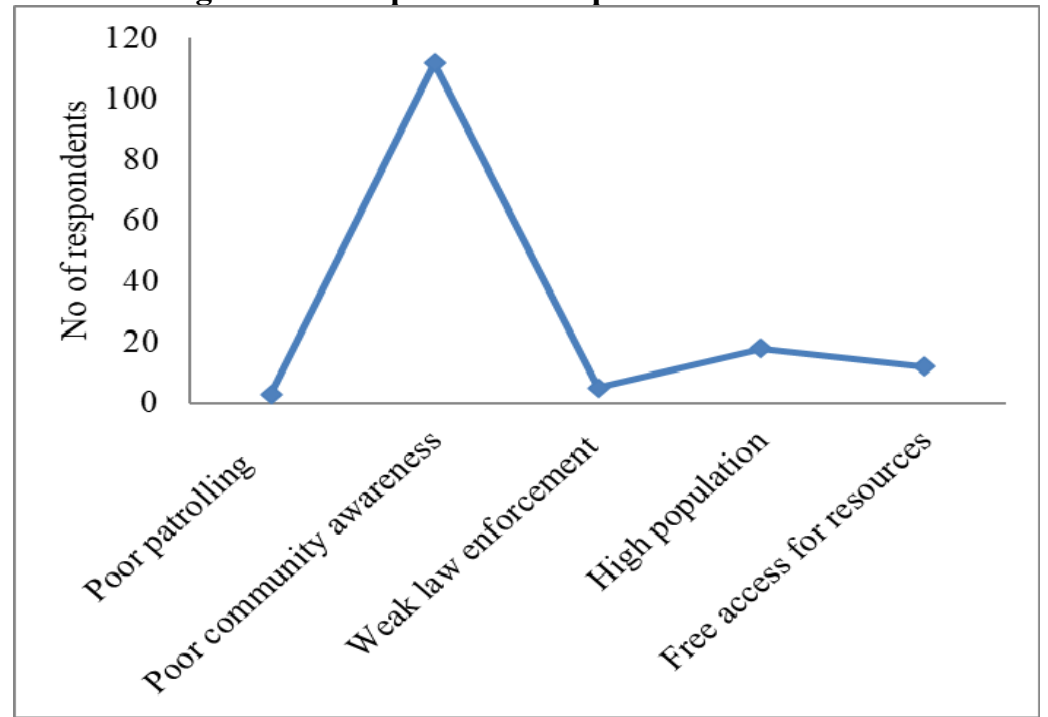

Fig 3: Major problems for effective management of elephants in KSNP

Currently so many problems were affected the management of African elephant conservation in KSNP. So the present finding indicated that poor community awareness was found the main problem for the implementation of African elephant management in KSNP. In addition to this high population, free access for resources, weak law enforcement and poor patrolling were other additional problems for the implementation of African elephant conservation. The present finding was disagreeing with previous findings of Oswin, 2009. Because in the previous finding the main problem for management of African elephant was poor patrolling but in the present finding poor community awareness was the main problem.

\section{What are the main threats of African elephant in the park?}

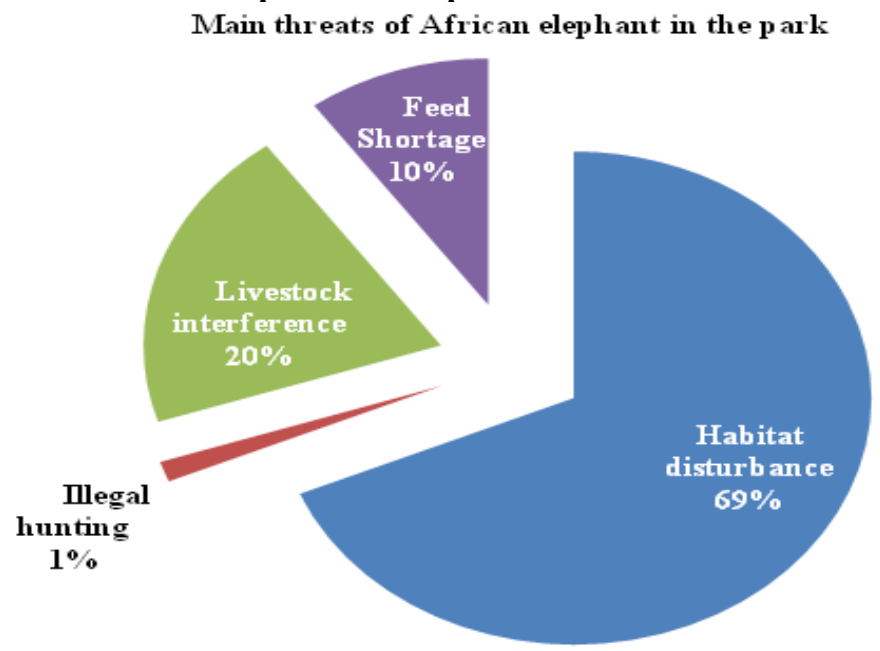

Fig 4: Main threats of African elephant in KSNP

As the pie chart indicated that $69 \%$ of the respondents responded that human disturbance was the main 
threat of African elephant in KSNP. In addition to this livestock interference (20), feed shortage $(10 \%)$ and illegal hunting (1\%) were some of additional threats of African elephant in KSNP. The present finding was in line with previous finding of Dawit Mamo, 2012. Because in both findings habitat disturbance was the main threat of African elephant in Kafta-shiraro national park.

Table 1. Rank the following points according their high problem related with the availability of African elephant in the park

\begin{tabular}{|l|l|l|}
\hline No & Item & Rank \\
\hline 1 & Elephants damage crops and are as good as pests & $\mathbf{1}^{\text {st }}$ \\
\hline 2 & Elephants provide revenue but it`s too little and inconsistent & $\mathbf{1 0}^{\text {th }}$ \\
\hline 3 & Elephants finish open water sources during the dry season & $\mathbf{9}^{\text {th }}$ \\
\hline 4 & Elephants reduce grazing area for livestock: no buffer zone for livestock & $\mathbf{2}^{\text {nd }}$ \\
\hline 5 & Availability of elephants causes social instability due to fear of wild animals & $\mathbf{4}^{\text {th }}$ \\
\hline 6 & Elephants reduce leisure time, for households are forced to sleep in fields to guard crops & $\mathbf{3}^{\text {rd }}$ \\
\hline 7 & Elephants take up land for the upcoming generation & $\mathbf{5}^{\text {th }}$ \\
\hline 8 & Availability of elephants cause injury and predation to livestock & $\mathbf{7}^{\text {th }}$ \\
\hline 9 & Availability of elephants reduce land for cultivation & $\mathbf{6}^{\text {th }}$ \\
\hline 10 & Availability of elephants induce threat, injury and death to humans & $\mathbf{8}^{\text {th }}$ \\
\hline
\end{tabular}

The above table indicated that the rank of points according their high problem related with the availability of African elephant in the park. So elephants damage crops and are as good as pests, elephants reduce grazing area for livestock: no buffer zone for livestock and elephants reduce leisure time, for households are forced to sleep in fields to guard crops were ranked from $1^{\text {st }}$ to $3^{\text {rd }}$ according their problem because of availability African elephant in KSNP.

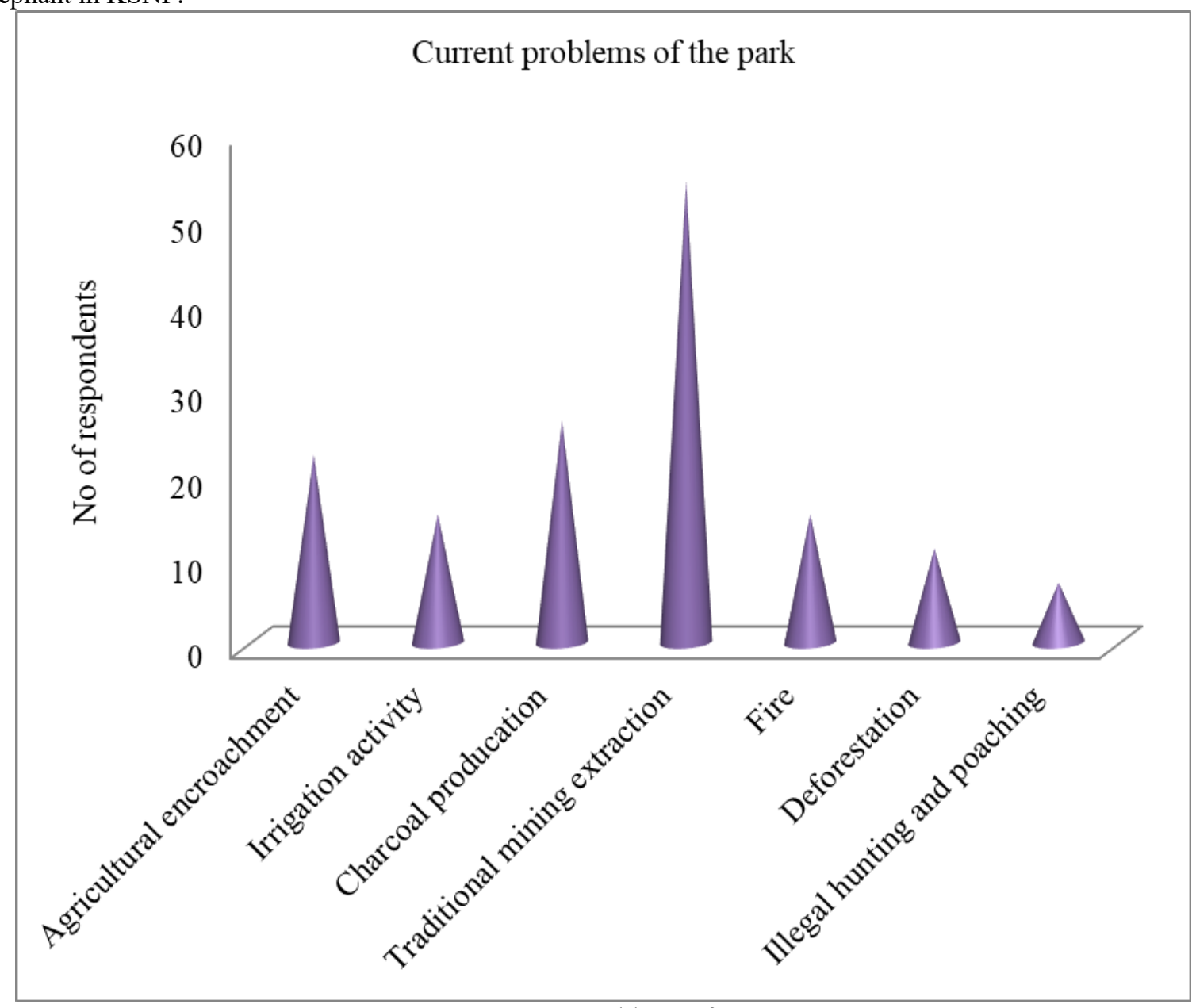

Fig 5: Current problems of KSNP

As the above table indicated that traditional mining extraction in KSNP was the main current problem that affected the overall biodiversity. In addition to this charcoal production and agricultural encroachment were other current problems that affect the park currently. 


\section{Recommendations}

Finally the researchers are recommended the following points.

$\checkmark$ Continuous training should be given for the local community especially for the individuals participated in the traditional mining activity to reduce the current problem

$\checkmark \quad$ Both governmental and nongovernmental organizations should work together to improve the tourism activity and to benefit the local community from the tourism activities

$\checkmark \quad$ Till there is research gap regarding the best conservation strategies particularly methods used to protect the crop damage by African elephant and to reduce the conflict between the local community and African elephant so researchers should initiate to fulfill this gap.

\section{Acknowledgments}

The authors acknowledges to Aksum University for financial and material support.

\section{REFERENCES}

Aref F, Redzuan M (2009). Level of Community Capacity Building for Tourism Development According To Types of Tourism Activities. Am. J. Sci. Res., 5:5-12.

Aref F, Redzuan M (2010). Community Leader's Perceptions towards Socio-Cultural Impacts of Tourism on Local Communities. J. Hum.Ecol., 29(2): 87-91.

Bromhead M, Bouzaher A, Castro G, Falconer J, Hamilton K, Kini R, Mackinnon K, Mearns R, Molnar A, Mott J, Riidihough I, Segnestam L (2000). Natural Resources Management. Draft for Discussion. Regional and Individual Submissions.

Dabour N (2003). Problems and Prospects of Sustainable Tourism Development in the OIC Countries: Ecotourism. J. Econ. Coop., 24(1):25-62.

Drumm A, Moore A (2002). An Introduction to Ecotourism Planning. Volume I. Arlington, U.S.A.

Ethiopian Wildlife Conservation Organization (1988). Elephant conservation Plan. Addis Ababa, Ethiopia.

Fernando, P, E, Wikramanayake, D, Weerakoon, L. K, Jayasinghe, M, Gunawardene, and Janaka, H 2005. Perceptions and patterns of human-elephant conflict in old and new settlements in Sri Lanka: insights for mitigation and management. Biodiversity and Conservation., 14:2465-2481.

Frankfurt Zoological Society (2007). Bale Mountains National Park, General Management Plan, 2007 - 2017 , Ethiopia.

Mekebebe Eshetu, Kumara Wakjira, and Minasie Gasdjaw (2002). Management plan of Kafta- Sheraro Wildlife Reserve (Draft document). Ethiopian Wildlife Conservation Organization, Addis Ababa. 59 pp.

Profit (2007). Country Profile of Ethiopia: Regional Investment Conference on Tourism in East Africa and the Indian Ocean. Kampala, Uganda.

Shoshani, J and Yirmed Demeke (2008). Report on the Kafta-Sheraro National Park. In memorial to Professor Jeheskel Shoshani. Tigray Region, Ethiopia.

Sikes, S, K (1971). The African elephant and its natural community life. The Trinity Press, London, UK. Pp. 256-285.

Sitati, N.W., Walpole, M.J., Smith, R.J. and Leader-Williams, N (2003). Predicting spatial aspects of humanelephant conflict. Journal of Applied Ecology., 40: 667-677.

Smith, R.J. and Kasiki, S.M (2002). African Elephant Specialist Group Report: A spatial analysis of humanelephant conflict in the Tsavo ecosystem. African Elephant Specialist Group, (SSC/ IUCN), WWF, Nairobi.

WTO (2009). Communication and Sustainable Tourism. Proceedings of the Global E-Conference and Summer Speaker Series on the Role of Development Communication in Sustainable Tourism. USAID. 


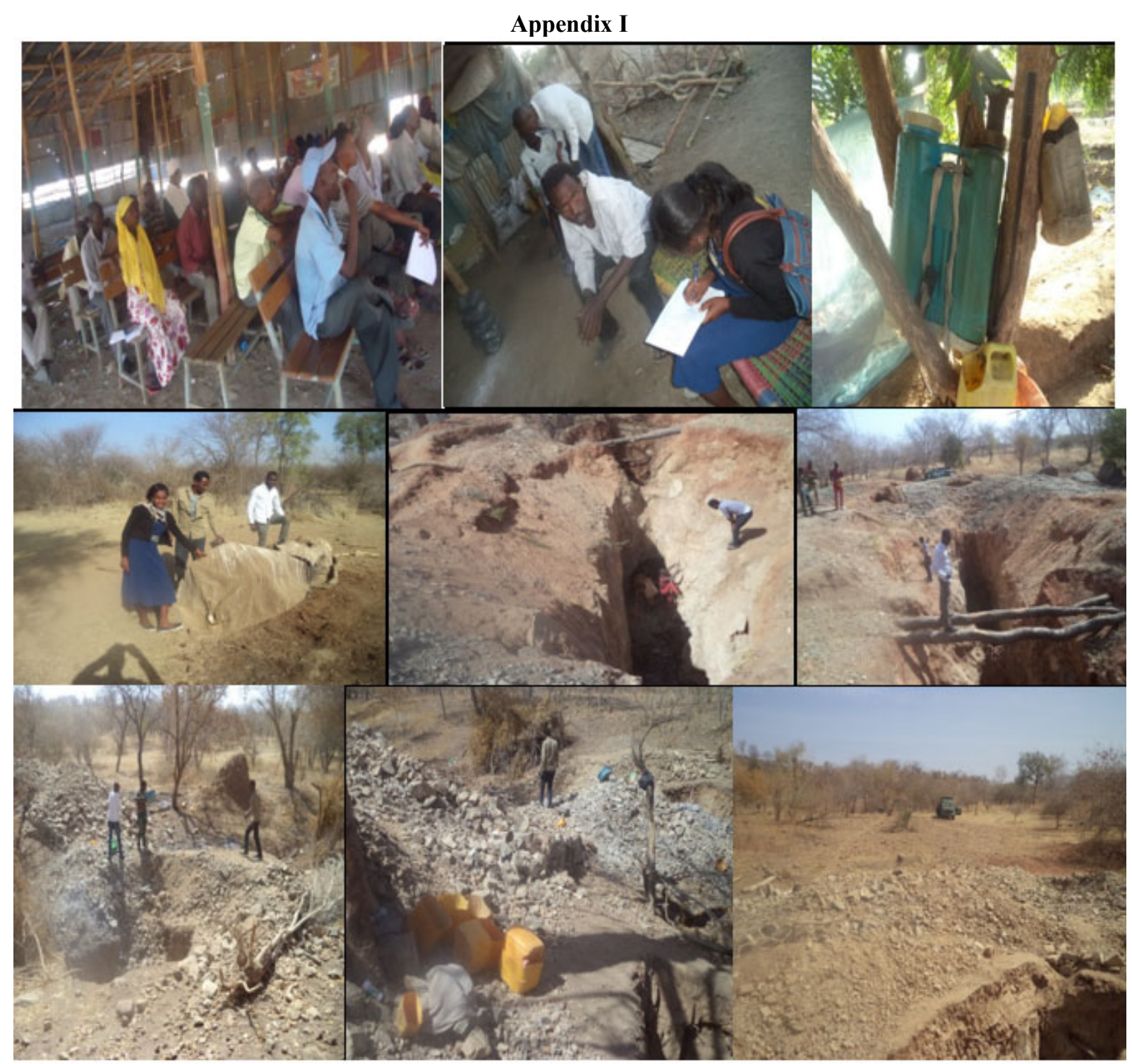

